\title{
Robert Wallace, M.A., LL.D., F.L.S.
}

Dr Robert Wallace, Professor of Agriculture and Rural Economy in the University of Edinburgh from 1885 to 1922, and Garton Lecturer on Colonial and Indian Agriculture from 1900 to 1922, died on January 17, I939, at the age of eighty-five at Mid Park House, Kincardine-on-Forth. He was a man of exceptional ability and great mental energy. For the thirty-seven years of his professorship he was recognised as the leading academic representative of agriculture in Scotland. Reared on the land, he inherited a love of the soil. Members of his family have been farming in Dumfriesshire and Galloway for nearly a century and a half. His father, the late $\mathrm{Mr}$ Samuel Wallace, Wallace Hall, Glencairn, was one of the largest and best-known farmers in the south of Scotland.

The future Professor received his early education at Tynron School and Hutton Academy. He proceeded later to the University of Edinburgh, where he studied under Professor Wilson, who held the Chair of Agriculture. After a brilliant academic career at the University he returned to the land, and for several years managed farms for his father, and also farmed for a time on his own account along with his brother, Mr S. Williamson Wallace who, in 1902, became Director of Agriculture for the State of Victoria in Australia.

Professor Wallace began his career as a teacher of Agriculture in I882, when he was appointed Professor of Agriculture for the Royal Agricultural College, Cirencester. Three years later he succeeded Professor Wilson as Professor of Agriculture and Rural Economy in the University of Edinburgh. Under his enlightened and energetic direction the curriculum for agricultural students was broadened and improved by the addition of a course in Forestry in 1885 , and by a course of lectures in Agricultural Entomology in I 89I. In I 900 a course of lectures on Colonial and Indian Agriculture, delivered by Professor Wallace himself, was added. In I 886 the University, acting on his advice, established the degree of B.Sc. in Agriculture. These developments greatly enhanced the status of the training given in agriculture: Edinburgh, in fact, became one of the leading schools of agriculture in the Empire.

Professor Wallace was a great traveller. His search for new knowledge regarding agricultural and pastoral conditions took him in $\mathrm{I} 887$ to Italy and India; in 1890,1892 , and 1898 to the United States; in I 891 to Egypt; in I891 and 1892 to Greece; in 1895 to South Africa; 
in I 896 to Australia and New Zealand; in 1907 to Canada, the United States, and Mexico; and in 1908 to Canada, the United States, and Rhodesia. Year by year he added to his stock of knowledge, and freely gave it out again to those whom he reached with his never-resting pen. He was a prolific writer both of books and of articles and letters for the Press. His best-known book was perhaps Farm Live-Stock of Great Britain, which went through several editions. Other books of his deal with agricultural and pastoral conditions in India, in Australia and New Zealand, and in Cape Colony. Some of his books, such as $A$ Country Schoolmaster, Eleanor Ormerod, LL.D., Heather and Moor Burning for Grouse and Sheep, are less formal in character; but all bear the stamp of his alert and inquiring mind.

His empire-wide reputation brought him into touch with the governing authorities and commercial concerns in many parts of the Empire, and his services in an advisory capacity were much in demand. In 1879 he went to Canada to report on that Dominion as a field for the emigration of agriculturists. In I 895 he visited Cape Colony on the invitation of the Government of South Africa. In 1893 he revisited Canada as a Special Commissioner to report to the Government at Ottawa on Highland Crofter Settlements in Manitoba. For five years he was consulting adviser to the British South Africa (Chartered) Company.

From his students' point of view he was the perfect professor. His lectures were characterised by their freshness of outlook: there was nothing bookish about them; for they were largely based on his own varied farming experience and the investigations which he himself had made during his wide travels. In his students he took a paternal interest, and through his influence many of them got their first appointments. In their subsequent careers he continued to keep in touch with them despite the fact that he was a very busy man. In losing him many of us have lost a true friend.

Professor Wallace was an LL.D. of Edinburgh; a Fellow of the Royal Scottish Geographical Society, and of the Royal Physical Society of Edinburgh, and a member of the Highland and Agricultural Society of Scotland.

He was a great patriot who dearly loved his country. His Letters to President Wilson, written in the early years of the Great War, reveals the ardent patriotism of the man, and it may be that these letters served their purpose in influencing the President towards bringing America into the war.

He was elected a Fellow in $\mathbf{I} 886$.

D. C. 